\title{
USING DRIED CHICORY (CICHORIUM INTYBUS L.) LEAVES HERBAL ADDITIVE IN RABBIT DIETS
}

\author{
Yasmin M.M. Mahmoud \\ Animal Production Research Institute, Agriculture Research Center, Ministry of Agric., Dokki, Giza, \\ Egypt.
}

(Received 13/11/2018, accepted $27 / 12 / 2018$ )

SUMMARY

\begin{abstract}
$\mathrm{T}$ his experiment was carried out to study the effect of some feed additives (dried chicory leaves) on growth performance of black Balady rabbits, nutrients digestibilities, feeding values, carcass traits, some blood constituents, and caecal activity. A total number of 48 weaned rabbits aged 6 weeks, with average body weight $740 \mathrm{~g}$ were used in this study. The experimental animals were individually housed and divided randomly into four similar groups (12 each) using complete randomized block design. Four experimental dietary treatments were designed by using the basal ration with the addition dried chicory leaves at $0.00,0.25$, 0.75 or $1.25 \mathrm{~g} /$ rabbits for control (T0) and tested rations $\mathrm{T} 1, \mathrm{~T} 2$ and $\mathrm{T} 3$, respectively. Results showed that, rabbits in $\mathrm{T} 2$ showed significantly $(\mathrm{P}<0.05)$ the highest live body weight $(\mathrm{LBW})$ and total gain followed by $\mathrm{T} 3$ and T1, while the lowest values were associated with (control) one at 10-14 weeks of age. Also the significant highest feed intake value was associated with the tested diet T2 in comparison with that of control and the other tested rations. Feed conversion and performance index were marked improved by the tested rations in comparison with control, however the differences among them did not significant. Also, digestion coefficients and feeding values were significantly the highest with $\mathrm{T} 2$ in comparison with the control one, but mostly the nutrients digestibilities and feeding values of the other tested rations were insignificant higher than those of control one. Almostly, carcass traits were significant $(\mathrm{P}<0.05)$ higher with all tested rations than those of control one. Rabbits in $\mathrm{T} 2$ showed significantly the highest $(\mathrm{P}<0.05)$ concentrations of total protein and albumin and insignificant higher for rabbits fed $\mathrm{T} 1$ and $\mathrm{T} 3$ chicory herb than those of control one. However, activities of Aspartate (AST) and Alanine (ALT) aminotransferase enzymes were significant $(\mathrm{P}<0.05)$ higher with all the tested treatments than those of control one, being the highest value was occurred with T2. Inversely, the concentrations of glucose, total cholesterol and uric acid were significant $(\mathrm{P}<0.05)$ lower with all tested rations than those of control one, being the lowest values were associated with T2 and T3 rations. And show that, no significant differences were found between treatments in caecal $\mathrm{pH}$ value. While, caecal TVFAs concentration was significantly increased $(\mathrm{P}<0.05)$, but ammonia concentration was decreased for rabbits fed $\mathrm{T} 2$ diet compared with T3 and control one. It could be concluded that diet of T2 led to an improvement in growth performance of rabbits and nutrients digestibility.
\end{abstract}

Keywords: Rabbits, chicory leave additives, growth performance, digestibility, carcass traits, blood biochemical, caecum activity.

\section{INTRODUCTION}

During the last decade and due to the pressure of high population worldly, an intensive animal production systems are becoming urgently use to secure the huge food demand for such highly growing world's population. Such great intensification system needs more significant changes in feeding systems and formulation the rations for animals than the traditional ones. There is a growing need for developing new supplements or feed additives and techniques that can improve animal performance, nutrients digestibility and milk production. Recently, there is a global trend in animal feed sector strongly suggest using natural source of feed additives such as herbs and medicinal plants which known to contain phytogentic compounds that have antioxidant, anticancer, antibacterial, antifungal and antiviral properties which could enhance animal health and productivity without harmful effects on human health or the environment (Das et al., 2016 and Walter, 1995). One of these herbs is chicory (Cicorium intybus L.), a perennial herb of the Asteraceae family indigenous to Europe, West Asia, Egypt, North America, and Italy. Chicory plant is grown primarily 
for its inulin content, which is one of the best-studied prebiotic sources in domestic animal application. Several studies have been carried out to describe the 'prebiotic effect' of chicory inulin type fructans and oligofructose (Castellini et al., 2007). According to the studies of Di Venere et al. (2009) on phenolic composition and antioxidant activity in wild chicory; they found the presence of caffeic acid derivatives and flavonoids (quercetin and kaempferol glycosides) could be induced a very high antioxidant activity compared to other wild edible species. Also, Behboud et al., (2011) showed that the highest levels of weight gain, feed intake and feed conversion ratio (FCR) was in group fed basal diet plus 200 ppm of both Nigella sativa $L$. and Cichorium intybus L. compared with the control one that free from these additives for chicken. In perspective, Cichorium intybus contains organic acid, alkaloid, saccharides, coumarins, triterpenes, sesquiterpenes, ect. where it has a function of lowering the blood lipid, glucose, decreasing hepatoprotection and uric acid as observed by Wang and Cui 2009. Also, Di Venere et al. (2009) However, information about the dry matter yield potential and bioactive compounds contents of natural species of chicory is still scarce, even if these details could be very helpful in establishing relationships such as that between forage polyphenol contents and their feeding values for ruminants. This work aimed to investigate the effect of chicory additives on rabbit diets with three levels of dried chicory leaves on the productive performance of growing rabbits, digestion coefficient, feeding values, carcass characteristics, blood parameters, biochemical traits of caecum activity and economical efficiency.

\section{MATERIALS AND METHODS}

The current work was carried out at Sakha Animal Production Research Station, Animal Production Research Institute, Agricultural Research Center, Ministry of Agriculture. Fresh chicory leaves were collected directly after harvest and chopped to $2-3 \mathrm{~cm}$ pieces with moisture content of $90 \%$ approximately, then sun-dried for 14 days and finally completely ground before mixing with the other ingredients for formulation the experimental rations for animals. Ingredients were analyzed for crude protein $(\mathrm{CP})$, crude fiber (CF), ether extract (EE) and ash according to AOAC (1996).

\section{Experimental rabbits and diets}

Fourty eight black Balady rabbits were chosen after weaned at 6 weeks of age and divided into four groups (12 rabbits each) according to initial body weight (740.21g LBW). The experimental period was extended from 6 to 14 weeks of age. All groups were fed the basal diet that presented in Table (1) in addition $0.00,0.25,0.75$ or $1.25 \mathrm{~g}$ of dried chicory leaves / rabbits for control (T0), tested rations (T1), (T2) and (T3), respectively to evaluate the utilization of dried chicory leaves in feeding growing rabbits. The experimental diets were formulated to be iso-caloric ( 2500 kcal DE $/ \mathrm{kg} \mathrm{diet)}$ and iso-nitrogenous ( 17\% CP). All diets were pelleted and contained adequate levels of nutrients to satisfy the nutrients requirements of growing rabbits according to AMD (1996). Chemical composition (calculated) of the basal diet are presented in Table (1).

\section{Housing and management}

Rabbits of each group were individually housed in galvanized wire cages $(40 \times 50 \times 60 \mathrm{~cm})$ and fresh water was automatically available at all time. All rabbits were kept under the same managerial, hygienic and environmental conditions, allowing recording feed intake individually.

\section{Experimental procedures}

Live body weight and feed intake were weekly recorded throughout the experimental feeding period. Then, daily weight gain, feed conversion and economic efficiency were calculated. Also, the performance index was calculated as:

$$
\mathrm{PI}=[\text { final live body weight }(\mathrm{kg}) / \text { feed conversion ratio }] \times 100 .
$$

\section{Digestibility trials}

Digestibility trials were undertaken at the last week of the feeding trial period on three animals from each group. Rabbits were individually housed in metabolic cages. The same feeding system and dietary treatments of the feeding trial were applied on digestibility trials. Individual feed intake was carefully determined and feces were daily collected quantitatively for 7- days collection period to determine the nutrients digestion coefficients and feeding values of the experimental diets. The daily samples of feces for 
each animal were immediately frozen at $-20^{\circ} \mathrm{C}$ until the end of the collection phase and, then composited samples for each animal was prepared for analysis. Faeces of each animal was mixed, dried at $60^{\circ} \mathrm{C}$ for 24 hours, then representative samples were ground for chemical analysis. Chemical analysis of diets and feces were determined according to AOAC (1996). The feeding values as TDN and DCP were calculated for the dietary treatments.

Table (1): Composition and calculated analysis of the experimental diet (as fed).

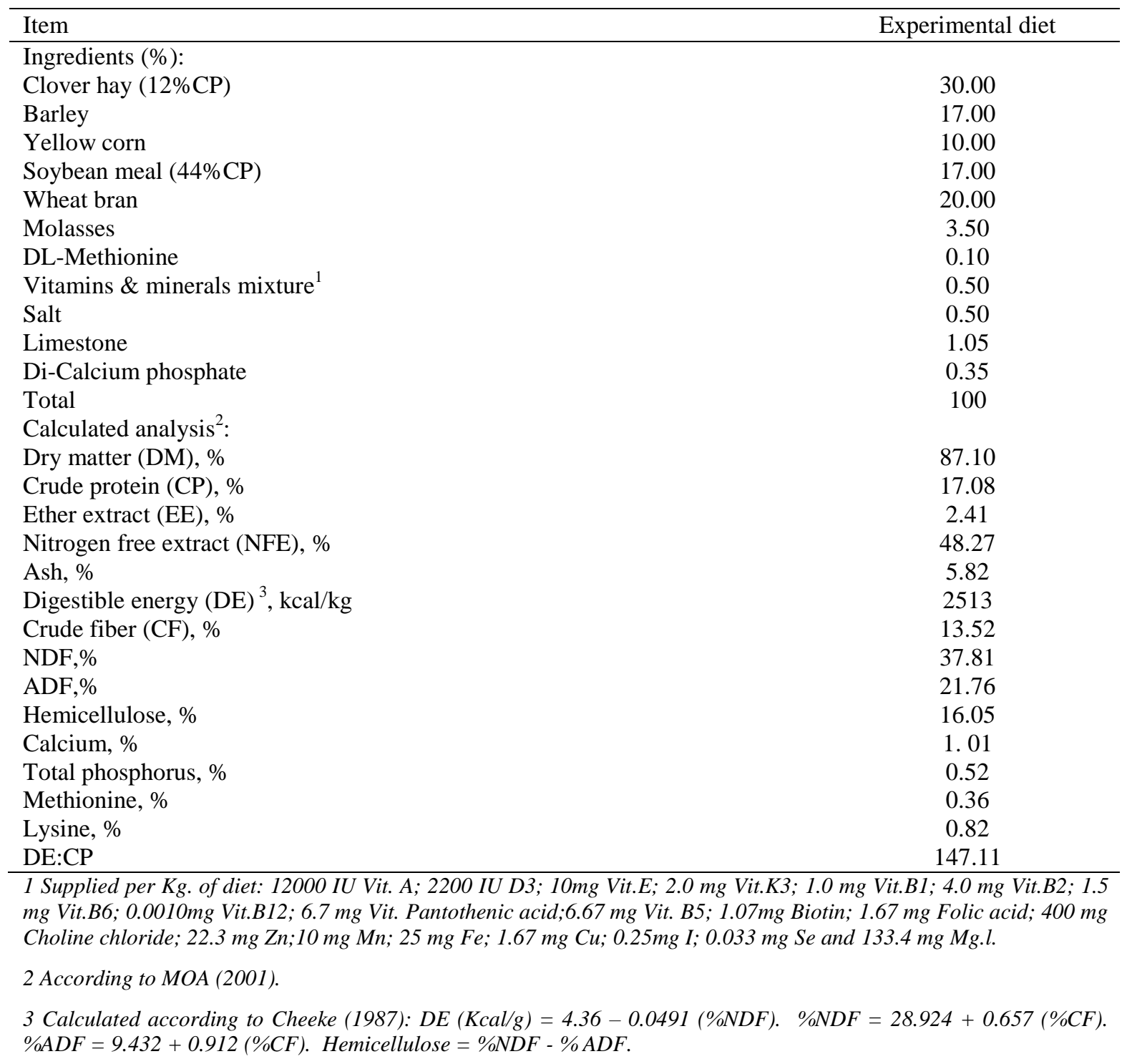

\section{Carcass traits}

At the end of the experimental period, 3 representative rabbits from each treatment were randomly chosen and fasted for 12 hours and individually weighed to record pre-slaughtering weight. After complete bleeding and skinning, the empty carcass with head, and giblet organs (heart, liver and kidneys) were weighed separately according to Blasco et al. (1993) to determine the carcass measurements.

\section{Blood parameters}

At the end of the experimental period, blood samples were collected from slaughtered rabbits (3 in each group) in clean sterile tubes containing few drops heparin solution for each animal immediately after 
slaughtering. Blood samples were centrifuged at 3000 r.p.m for 15 minutes and, then plasma was separated and stored at $-20^{\circ} \mathrm{C}$ until used for analysis. Plasma was used for determination total protein by the Biuret method according to Henry et al. (1974), total albumin (Doumas et al., 1971) and globulin concentration was calculated as the difference between total protein and albumin. Creatinine was determined according to Henry et al. (1974) and plasma glucose was determined according to the procedure of Coles (1986). Assay of plasma Aspartate (AST) and Alanine (ALT) aminotransferase activities were conducted according to procedures of Reitman and Frankel (1957), Total cholesterol was determined according to Allian et al. (1974) using bio Merieux test kits, and Uric acid was determined according to Tietz (1986). All biochemical blood constituents were determined using spectrophotometer (Spectronic 21 DUSA) and commercial diagnostic kits (Combination, Pasteur Lap.).

\section{Caecum activity}

Samples of caecum contents were taken individually from three animals from each group after slaughter at the end of the experimental period after being fasted for $12 \mathrm{hrs}$. Caecal contents of slaughtered rabbits were obtained and, then strained through four folds of gauze and divided into three portions. The first portion was used immediately for the estimation $\mathrm{pH}$ using Bechman $\mathrm{pH}$ meter and the second portion was used immediately for estimation Ammonia- $\mathrm{N}$ concentration by applying the micro-diffusion method according to Conway (1963), while the third portion was preserved by addition of $1 \mathrm{ml} \mathrm{N} / 10 \mathrm{HCL}$ and $2 \mathrm{ml}$ orthophosphoric acid to each $2 \mathrm{ml}$ of ceacum contents juice for determination of total volatile fatty acid (TVFAs) concentration according to Warner (1964).

\section{Economical efficiency}

Economical efficiencies was calculated as the ratio between incomes price of weight gain and the cost of feed consumed over 6-14 weeks of age.

\section{Statistical analysis}

The obtained data were statistically analyzed using one-way analysis of variance procedure (SAS, 2000) computer program using the following fixed model:

$$
\mathrm{Yi}=\mu+\mathrm{Ti}+\mathrm{ei}
$$

Where $\mathrm{Yi}=$ The individual observation; $\mu=$ Overall mean; $\mathrm{Ti}=$ Effect of treatments. $(\mathrm{i}=1,2,3$ and 4$)$; ie $=$ Random error component assumed to be normally distributed. Significant differences between treatment means were determined at $P<0.05$ by Duncan's multiple-range test (Duncan's, 1955).

\section{RESULTS AND DISSCUSSION}

\section{Chemical composition}

Chemical analysis of chicory leaves are presented in Table (2). It have relatively high contents of macronutrients of $\mathrm{CP}$, EE and NFE and as well as very suitable content of CF and in addition chicory plant are very rich in many vital of biochemical compounds as have been recorded in the literature. These results were found to be in the range of the values recorded by Monti et al., (2005) who found that crude protein and ash ranged from 8.56 to 15.73 and 9.58 to $13.75 \%$, respectively.

On the other hand, Adamoli and Rigon (2001) reported that chicory root contained 15-20\% inulin and 510\% oligofructose. Also, Moussa et al., 2005 and Mona et al., 2009 showed that the chicory leaves were contained $10.95 \%$ inulin, and they found that, in chicory leaves, Caffeic acid was the major phenolic compound presented, followed by Chlorogenic acid, P. hydrobenzoic acid, P.coumaric acid, Protocatechuic, Gallic and Iso vanillic acid in descending order. Also, Di Venere et al. (2009) on phenolic composition and antioxidant activity in wild chicory, they found the presence of caffeic acid derivatives and flavonoids (quercetin and kaempferol glycosides) could be induced a very high antioxidant activity compared to other wild edible species. 
Table (2): Chemical analysis of the chicory leaves \% (on DM basis).

\begin{tabular}{|c|c|c|c|c|c|c|c|}
\hline \multirow{3}{*}{ Chicory Leaves } & \multicolumn{7}{|c|}{ Item } \\
\hline & DM & $\mathrm{OM}$ & $\mathrm{CP}$ & CF & $\mathrm{EE}$ & NFE & Ash \\
\hline & 90.15 & 88.67 & 15.24 & 17.13 & 3.42 & 52.88 & 11.33 \\
\hline
\end{tabular}

\section{Productive performance}

Effect of chicory leaves inclusion in the diets on growth measurements are presented in Table (3). The average initial live body weight (LBW) was fairly similar in different experimental diets, it ranged between $720.83 \mathrm{~g}$ and $773.75 \mathrm{~g}$. Respecting LBW at $10 \mathrm{wks}$ of age, results showed non-significant differences among the experimental treatments, while at 14 -wk of age, $0.75 \mathrm{~g}$ chicory-ration (T2) gave significant higher LBW than that of $0.25 \mathrm{~g}$-chicory-ration (T1) and control one (T0), but insignificant higher than that associated with (T3) which have the higher percentage of chicory leaves (1.25 g). Similar trend among the dietary treatments was observed with the measurement of total body gain, being the highest value was occurred with T2-ration and the lowest one was associated the control-ration (T0). With regard to other studies in the literature, results of this study are consistent in some instances and inconsistent in other. These findings are in agreement with those reported by SooBo (2005) who found that addition chicory or inulin into the diets of monogastric animals (rabbit, chicken, pig and rat) could be positively affecting on growth performance, especially in young animals. On the other hand, Ali Mirza Aghazadeh and Elena Nabiyar (2015) mentioned

Table (3): Productive performance as affected by chicory levels in the diets of growing rabbits.

\begin{tabular}{|c|c|c|c|c|c|}
\hline \multirow{2}{*}{ Item } & \multicolumn{4}{|c|}{ Treatment } & \multirow{2}{*}{$\pm \mathrm{SE}$} \\
\hline & T0 & $\mathrm{T} 1$ & $\mathrm{~T} 2$ & $\mathrm{~T} 3$ & \\
\hline \multicolumn{6}{|l|}{ Live body weight $(\mathrm{g})$ : } \\
\hline Initial wt. (6weeks) & 720.83 & 731.66 & 773.75 & 734.58 & \pm 13.15 \\
\hline 10 weeks & 1251.32 & 1284.60 & 1366.70 & 1344.17 & \pm 25.81 \\
\hline 14 weeks & $1707.51^{\mathrm{c}}$ & $1769.22^{\mathrm{bc}}$ & $1929.61^{\mathrm{a}}$ & $1859.63^{a b}$ & \pm 26.80 \\
\hline \multicolumn{6}{|l|}{ Total gain $(\mathrm{g})$ : } \\
\hline 6-10 weeks & 530.42 & 552.92 & 592.92 & 609.59 & \pm 22.17 \\
\hline 10-14 weeks & 456.25 & 484.58 & 562.92 & 515.42 & \pm 22.25 \\
\hline 6-14 weeks & $986.67^{\mathrm{b}}$ & $1037.50^{\mathrm{ab}}$ & $1155.81^{\mathrm{a}}$ & $1125.00^{\mathrm{ab}}$ & \pm 27.94 \\
\hline \multicolumn{6}{|l|}{ Total feed intake $(\mathrm{g})$ : } \\
\hline 6-10 weeks & $1749.22^{d}$ & $1775.43^{c}$ & $1855.83^{\mathrm{a}}$ & $1817.52^{b}$ & \pm 6.75 \\
\hline 10-14 weeks & $2209.20^{\mathrm{c}}$ & $2381.72^{b}$ & $2521.71^{a}$ & $2365.02^{b}$ & \pm 17.17 \\
\hline 6-14 weeks & $3958.31^{c}$ & $4157.11^{b}$ & $4377.54^{\mathrm{a}}$ & $4182.51^{\mathrm{b}}$ & \pm 22.73 \\
\hline \multicolumn{6}{|c|}{ Feed conversion ratio (g feed/g gain): } \\
\hline 6-10 weeks & 3.71 & 3.50 & 3.18 & 3.31 & \pm 0.162 \\
\hline 10-14 weeks & 5.52 & 5.18 & 5.06 & 5.18 & \pm 0.280 \\
\hline 6-14 weeks & 4.07 & 4.24 & 3.82 & 3.92 & \pm 0.110 \\
\hline \multicolumn{6}{|l|}{ Performance index ${ }^{1} \%$ : } \\
\hline 6-10 weeks & 39.63 & 41.37 & 44.24 & 46.44 & \pm 2.37 \\
\hline $10-14$ weeks & 35.50 & 36.57 & 43.40 & 41.35 & \pm 2.02 \\
\hline 6-14 weeks & 42.97 & 45.25 & 51.14 & 51.01 & \pm 1.78 \\
\hline \multicolumn{6}{|c|}{$\begin{array}{l}a, b, c \text { and } d: \text { means in the same row with different superscripts are significantly }(P \leq 0.05) \text { different. } \\
=\text { standard error. }\end{array}$} \\
\hline \multicolumn{6}{|c|}{$\begin{array}{l}\text { Calculated according to North (1981): } \quad{ }^{1} \text { Performance index } \%=\text { final live body weight }(\text { Kg)/feed } \\
\text { conversion* } 100 .\end{array}$} \\
\hline
\end{tabular}


that, neither chicory root powder (CRP) inclusion at levels $1.5 \%, 3.0 \%$ or $4.5 \%$ nor wheat-based diets affected body weight gain (BWG) of chicken from $1 \mathrm{~d}$ to $21 \mathrm{~d}$ of age. However, BWG of $4.5 \%$ CRP diet was significantly $(\mathrm{P}<0.05)$ lower than that of control treatment during the growth period of $(21-42 \mathrm{~d})$ and whole trail period (1-42 d). The inclusion of $4.5 \%$ CRP had a negative effect on BWG, such result could be indicating that the effects of CRP inclusion may change with age and the development of the bird's intestinal microbiota.

Regarding the feed intake data (Table 3), rabbits in T2 group showed significantly $(\mathrm{P}<0.05)$ the highest total feed intake (FI) at each age interval as compared with those fed the control diet and the other tested rations (T1 and T3). Similarly, Castellini et al. (2007) showed that rabbits fed fresh chicory (leaves and roots) recorded a higher DG (35.3 vs. $33.7 \mathrm{~g} / \mathrm{d}$; $\mathrm{P}<0.05)$ and FI (134.0 vs. $124.5 \mathrm{~g} / \mathrm{d}, \mathrm{P}<0.05)$ v.s. control diet that free from this plant. Also, Behboud et al. (2011) showed that the highest levels of WG and FI were observed in group fed basal diet plus $200 \mathrm{ppm}$ of both (Nigella sativa L. and Cichorium intybus L.) and the group fed basal diet plus antibiotic ( $4.5 \mathrm{mg}$ flavophospholipol $/ \mathrm{kg}$ diet) compared with those of control one which did not having any additive for chicken.

Concerning feed conversion, results showed that the differences respecting feed conversion (feed/gain) and growth performance index did not significant different $(\mathrm{P}>0.05)$ among the dietary treatments and overall ages of the rabbits as shown in Table (3), being the best value was recorded for rabbits fed diet containing $0.75 \mathrm{~g}$ (T2) and the poorest one was occurred with control one. Earlier, Ali Mirza Aghazadeh and Elena Nabiyar (2015) with chicken and Volk and Marounek (2011) with rabbits, demonstrated that, no significant effect respecting feed conversion ratio (FCR) of the diet included chicory root-ration compared with the diet that free from this ingredient. In contrary results here are different with those reported by Behboud et al. (2011) who found that the best FCR was associated with the basal diet plus $200 \mathrm{ppm}$ of both Nigella sativa L. and Cichorium intybus L. for chicken compared with the control one (without additive).

\section{Nutrients digestibility and feeding values}

Results of nutrients digestibility and feeding values of experimental diets are given in Table (4). The obtained results indicated that digestibility of all nutrients, except $\mathrm{CP}$ were significant $(\mathrm{P}<0.05)$ higher for $0.75 \mathrm{~g}$ chicory-ration (T2) than those of the control one (T0), while mostly there were non significant differences among the other tested rations (T1 and T3) and control ration, respecting most nutrients. Regarding, crude protein (CP), results cleared that no significant change due to the addition of different levels of chicory into the diets of rabbits. These results were reflected on the feeding values in term of total digestible nutrient (TDN) value that behaved similar trend to that of nutrients digestibilities among the dietary treatments of the experiment, being the highest value was occurred with (T2)-ration. In the meantime, insignificant difference was observed for DCP among diets. This preference may be due to the ability of the chicory intybus herb to purification of the digestion track from the parasites that may affect the balance of the rumen environment and therefore adversely affect the process of digestion of different nutrients (Athanasiadou et al., 2007). Additional such additive could be provide a suitable environment for the growth of beneficial microflora in the rumen. In line with the present results, Sanderson et al. (2003) and Scharenberg et al. (2007) mentioned that chicory forage is considering a good source of minerals and vital compound, highly palatable with good digestion for livestock and poultry. Regarding the addition of herbs into rations of farm animals, it could be improving rumen fermentation and digestibility (Ando et al., 2003). Additionally, El Basiony et al. (2015) showed that the results of lactating goats fed diet containing $10 \mathrm{~g}$ Cichorium intybus gave better utilized of diet than the control diet respecting all nutrients digestibilies (DM, OM, EE, CP, CF, and NFE). Furthermore, Abu-Zied (1988) indicated that effective substances in medicinal plants could act as antiseptic against the antagonistic microbes and stimulate enzymes and digestive processes. Specifically, Socode (2011) found that using beet pulp, apple or citrus pulp as a sources of digestible or soluble fibers in rabbit diets could be replaced by chicory pulp that known for its high content of inulin and pectin (minimum $7 \%$ and $27 \%$, respectively). Chicory pulp is the dried and ground product obtained after partial extraction of inulin by diffusion of the chicory root shreds. Chicory pulp contains on average $87 \% \mathrm{DM}, 8.8 \% \mathrm{CP}, 32.0 \% \mathrm{NDF}, 24.0 \% \mathrm{ADF}$ and $2.0 \% \mathrm{ADL}$. 
Table (4): Digestion coefficients and feeding values as affected by chicory levels in the diets of growing rabbits.

\begin{tabular}{|c|c|c|c|c|c|}
\hline \multirow{2}{*}{ Digestibility (\%) } & \multicolumn{4}{|c|}{ Treatment } & \multirow{2}{*}{$\pm \mathrm{SE}$} \\
\hline & T0 & T1 & $\mathrm{T} 2$ & T3 & \\
\hline DM & $62.20^{b}$ & $65.39^{a b}$ & $70.18^{a}$ & $68.94^{\mathrm{a}}$ & \pm 1.25 \\
\hline $\mathrm{OM}$ & $65.77^{\mathrm{b}}$ & $68.45^{a b}$ & $72.81^{\mathrm{a}}$ & $71.21^{\mathrm{ab}}$ & \pm 1.14 \\
\hline $\mathrm{CP}$ & 69.51 & 69.71 & 73.04 & 71.31 & \pm 0.977 \\
\hline $\mathrm{CF}$ & $29.54^{b}$ & $35.15^{a b}$ & $43.61^{\mathrm{a}}$ & $40.78^{a b}$ & \pm 2.40 \\
\hline $\mathrm{EE}$ & $78.52^{b}$ & $80.35^{a b}$ & $82.79^{a}$ & $81.27^{\mathrm{ab}}$ & \pm 0.684 \\
\hline NFE & $72.48^{b}$ & $75.31^{\mathrm{ab}}$ & $79.14^{\mathrm{a}}$ & $77.84^{\mathrm{a}}$ & \pm 1.01 \\
\hline \multicolumn{6}{|c|}{ Feeding values (\%): } \\
\hline TDN & $62.72^{b}$ & $65.24^{a b}$ & $69.29^{\mathrm{a}}$ & $67.75^{\mathrm{ab}}$ & \pm 1.02 \\
\hline DCP & 13.15 & 13.21 & 13.88 & 13.64 & \pm 0.23 \\
\hline
\end{tabular}

Means bearing different letter superscripts ( $a$ and $b$ ) within the same row are significantly $(P \leq 0.05)$. SE $=$ standard error. $T 0=$ group fed the basal diet (control), $T 1=$ group fed the basal diet with $0.25 \mathrm{~g}$ chicory, $T 2=$ group fed the basal diet with $0.75 \mathrm{~g}$ chicory and $T 3=$ group fed the basal diet with 1.25 g chicory.

\section{Carcass characteristics}

Carcass characteristics of the black Balady rabbits are shown in Tables (5 and 6). Results showed that pre-slaughter weight and the weights and percentages of empty carcass weight with head were significant $(\mathrm{P}<0.05)$ higher with the three tested rations than those of control one. Dressing percentage was significant $(\mathrm{P}<0.05)$ higher with the three tested rations of chicory leaves than that of control one. Approximately, the values of weights and percentages of total giblets and non edible parts seemed to be have not clear trends among the dietary treatments. Mostly, weights of head and giblet organs (liver, heart and kidney) were markedly higher with all tested rations compared with those of control. These findings are in agreement with those reported by Castellini et al. (2007) who illustrated that feeding fresh chicory slightly increased the post weaning rabbits (52 d) and slaughtering weight (77 d) compared with the control group. Also, Yusrizal and

Table (5): Carcass traits as affected by chicory levels in the diets of growing rabbits.

\begin{tabular}{|c|c|c|c|c|c|c|c|c|c|}
\hline \multirow{3}{*}{ Treatment } & \multicolumn{9}{|c|}{ Carcass trait } \\
\hline & \multirow{2}{*}{$\begin{array}{c}\text { (Pre- } \\
\text { slaughte) } \\
\text { Fasting } \\
(\mathrm{g})\end{array}$} & \multicolumn{2}{|c|}{ Empty carcass } & \multicolumn{2}{|c|}{ Total giblets } & \multicolumn{2}{|c|}{$\begin{array}{c}\text { Dressing } \\
\text { (Total edible parts) }\end{array}$} & \multicolumn{2}{|c|}{ Non edible parts } \\
\hline & & (g) & $\%$ & (g) & $\%$ & (g) & $\%$ & (g) & $\%$ \\
\hline T0 & $1743.33^{\mathrm{c}}$ & $883.33^{b}$ & $50.70^{c}$ & $77.47^{b}$ & 4.44 & $960.80^{b}$ & $55.15^{\mathrm{c}}$ & 782.53 & $44.85^{\mathrm{a}}$ \\
\hline $\mathrm{T} 1$ & $1971.67^{\mathrm{b}}$ & $1036.67^{\mathrm{a}}$ & $52.60^{b c}$ & $86.57^{\mathrm{ab}}$ & 4.40 & $1123.24^{\mathrm{a}}$ & $56.98^{\mathrm{bc}}$ & 848.43 & $43.02^{\mathrm{ab}}$ \\
\hline $\mathrm{T} 2$ & $2030.00^{\mathrm{a}}$ & $1166.00^{\mathrm{a}}$ & $57.47^{\mathrm{a}}$ & $91.40^{\mathrm{a}}$ & 4.53 & $1257.40^{\mathrm{a}}$ & $62.00^{\mathrm{a}}$ & 772.60 & $38.00^{\mathrm{c}}$ \\
\hline $\mathrm{T} 3$ & $1985.00^{\mathrm{ab}}$ & $1108.33^{a}$ & $55.97^{a b}$ & $85.70^{a b}$ & 4.34 & $1194.03^{\mathrm{a}}$ & $60.27^{a b}$ & 790.97 & $39.73^{b c}$ \\
\hline \pm SE & \pm 50.16 & \pm 37.54 & \pm 0.988 & \pm 1.98 & \pm 0.092 & \pm 38.72 & \pm 0.978 & \pm 23.54 & \pm 0.978 \\
\hline $\begin{array}{l}a, b \text { an } \\
\text { SE = stan } \\
\text { Total edi } \\
\text { Heart wt. } \\
\text { Total edi }\end{array}$ & $\begin{array}{l}c: \text { means } \\
\text { d error. } \\
\text { parts } w t .=\end{array}$ & $\begin{array}{l}\text { in the sam } \\
\text { Empty carcas }\end{array}$ & $\begin{array}{l}\text { column } \\
\text { t. (with h }\end{array}$ & $h$ differen & supersct & $\begin{array}{l}\text { are sign } \\
\text { lible gible }\end{array}$ & antly $\quad(P$ & $\begin{array}{ll}0 . & 05)\end{array}$ & $\begin{array}{l}\text { lifferent. } \\
y s w t .+\end{array}$ \\
\hline
\end{tabular}


Chen (2003) resulted that adding chicory inulin and fructo-oligosaccharides (FOS) at $10 \mathrm{~g} / \mathrm{kg}$ diet improved BWG, carcass weight, carcass percentage and lowering the abdominal fat content in chicken. Similarly, Behboud et al. (2011) found that higher percent of liver and lower level of abdominal fat were occurred in basal diet plus 200 ppm of both Nigella sativa and Cichorium intybus for chicken compared with the control one (without additive). While these results are opposite to those recorded by Ali Mirza Aghazadeh and Elena Nabiyar (2015) who mentioned that there were no significant effects of chicory root powder (CRP) inclusion on relative weights of internal organs and carcass traits of chicken. Similar results were also reported by Waldroup et al. (1993). Finally, Nobakht Ali (2011) found that using different levels of chicory numerically improved the small intestine, gizzard and liver percent. The lowest percent of abdominal fat and the highest percent of thigh were observed by using 1 and $1.5 \%$ of chicory and could be related to relatively the lowest percent of carcass and breast percent of male broilers. Pointdly, Ibolya Kocsis et al. (2003) resulted that using chicory extract supplementation either by normal or by lipid rich diet at $2 \mathrm{~g} / \mathrm{kg}$ body weight beneficial effect was verified on pancreas status in young male Fisher rats in experimental dislipidemia.

Table (6): Edible giblets of carcass as affected by chicory levels in the diets of growing rabbits.

\begin{tabular}{|c|c|c|c|c|c|c|c|c|}
\hline \multirow{3}{*}{ Treatment } & \multicolumn{8}{|c|}{ Edible giblet } \\
\hline & \multicolumn{2}{|c|}{ Head } & \multicolumn{2}{|c|}{ Liver } & \multicolumn{2}{|c|}{ Heart } & \multicolumn{2}{|c|}{ Kidney } \\
\hline & (g) & $\%$ & (g) & $\%$ & (g) & $\%$ & (g) & $\%$ \\
\hline T0 & $85.00^{c}$ & 4.90 & $59.10^{b}$ & 3.39 & $5.43^{b}$ & $0.31^{b}$ & 12.93 & 0.74 \\
\hline $\mathrm{T} 1$ & $105.00^{b}$ & 5.33 & $65.74^{\mathrm{ab}}$ & 3.34 & $7.07^{\mathrm{a}}$ & $0.36^{\mathrm{ab}}$ & 13.77 & 0.70 \\
\hline $\mathrm{T} 2$ & $117.33^{\mathrm{a}}$ & 5.80 & $68.17^{\mathrm{a}}$ & 3.37 & $8.23^{\mathrm{a}}$ & $0.41^{a}$ & 15.00 & 0.75 \\
\hline $\mathrm{T} 3$ & $113.33^{a b}$ & 5.77 & $65.50^{\mathrm{ab}}$ & 3.32 & $7.20^{\mathrm{a}}$ & $0.36^{\mathrm{ab}}$ & 13.00 & 0.65 \\
\hline$\pm \mathrm{SE}$ & \pm 4.00 & \pm 0.170 & \pm 1.50 & \pm 0.0794 & \pm 0.355 & \pm 0.012 & \pm 0.807 & \pm 0.04 \\
\hline
\end{tabular}

$a, b$ and $c:$ means in the same column with different superscripts are significantly $(P \leq 0.05)$ different.

${ }^{I}$ : On relative to pre-slaughter weight (fasted weight).

$T 0=$ group fed the basal diet (control), $T 1=$ group fed the basal diet with $0.25 \mathrm{~g}$ chicory, $T 2=$ group fed the basal diet with $0.75 \mathrm{~g}$ chicory and $\mathrm{T} 3=$ group fed the basal diet with $1.25 \mathrm{~g}$ chicory.

\section{Blood biochemical Parameters}

Results of blood parameters of rabbits fed the experimental rations are presented in Table (7). Total protein $(\mathrm{TP})$ and albumin $(\mathrm{AL})$ concentrations were significant higher $(\mathrm{P}<0.05)$ for rabbits received the mid level (T2) of chicory and insignificant higher for rabbits fed the low and high levels of chicory plant rations, than those of control one (T0). However, activities of Aspartate (AST) and Alanine (ALT) aminotransferase enzymes were significant $(\mathrm{P}<0.05)$ higher with all the tested treatments than those of control one, being the highest value was occurred with 0.75 g-chicory ration (T2). Inversely, the concentrations of glucose, total cholesterol and uric acid were significant $(\mathrm{P}<0.05)$ lower with all tested rations than those of control one, being the lowest values were associated with $\mathrm{T} 2$ and $\mathrm{T} 3$ rations whose the higher levels of dried chicory leaves. Also, results of the present study showed that, the rest of other blood metabolites (globulin and creatinine) concentrations were significantly unaffected by the additive levels of chicory. So, these parameters showing improved renal and liver functions due to chicory addition into the diet of rabbits. Similar results were reported by Hanna and Mokhtar (2010) who showed that rats received chicory at level of $10 \% \mathrm{w} / \mathrm{w}$ clearly increased significantly serum total protein and albumin in comparison with those of unreceived one. Also, Craig (1999) cleared that albumen working considerably as a one of the important proteins that keeps the osmotic pressure stable in the blood. Both albumen and globulin results reflect the ability of animals to store reserve proteins even after their bodies have reached maximum capacity of depositing tissues (Stroev, 1989). Also, in line with the present results, Wang and Cui (2009) recorded that Cichorium intybus contains organic acid, alkaloid, saccharides, coumarins, triterpenes, sesquiterpenes, ect. where all these vital compounds could be functionally lowering the blood lipid and glucose, decreasing hepatoprotection and uric acid. Serum total cholesterol, triglycerides and low density lipoprotein (LDL) 
concentrations were significantly $(\mathrm{P}<0.05)$ reduced in groups of chicken fed basal diet plus $200 \mathrm{ppm}$ of both Nigella sativa L. and Cichorium intybus L. compared to the control group (Behboud et al., 2011).

Table (7): Blood parameters as affected by chicory levels in the diets of growing rabbits.

\begin{tabular}{|c|c|c|c|c|c|}
\hline \multirow{2}{*}{ Item } & \multicolumn{5}{|c|}{ Treatment } \\
\hline & T0 & $\mathrm{T} 1$ & $\mathrm{~T} 2$ & $\mathrm{~T} 3$ & $\pm \mathrm{SE}$ \\
\hline Total protein $(\mathrm{g} / \mathrm{dl})$ & $7.13^{b}$ & $7.19^{\mathrm{ab}}$ & $7.53^{\mathrm{a}}$ & $7.34^{\mathrm{ab}}$ & \pm 0.067 \\
\hline Albumin $(\mathrm{g} / \mathrm{dl})$ & $3.83^{b}$ & $3.91^{\mathrm{ab}}$ & $4.05^{\mathrm{a}}$ & $3.97^{\mathrm{ab}}$ & \pm 0.035 \\
\hline Globulin (g/dl) & 3.30 & 3.28 & 3.48 & 3.37 & \pm 0.066 \\
\hline AST (U/ l) & $35.80^{c}$ & $39.42^{b}$ & $43.02^{\mathrm{a}}$ & $41.12^{b}$ & \pm 0.834 \\
\hline ALT (U/ 1) & $21.63^{\mathrm{c}}$ & $24.00^{\mathrm{b}}$ & $27.23^{\mathrm{a}}$ & $26.0^{\mathrm{a}}$ & \pm 0.667 \\
\hline Glucose (mg/dl) & $111.91^{\mathrm{a}}$ & $86.19^{b}$ & $82.18^{\mathrm{d}}$ & $84.19^{c}$ & \pm 3.641 \\
\hline Total cholesterol (mg/dl) & 187. $80^{a}$ & $180.60^{b}$ & $172.80^{\mathrm{d}}$ & $177.73^{c}$ & \pm 1.660 \\
\hline Uric acid (mg/ dl) & $5.93^{\mathrm{a}}$ & $5.52^{\mathrm{b}}$ & $5.32^{\mathrm{c}}$ & $5.11^{\mathrm{d}}$ & \pm 0.093 \\
\hline Creatinine (mg/dl) & 1.86 & 1.89 & 1.81 & 1.86 & \pm 0.028 \\
\hline
\end{tabular}

\section{Caecum activity}

Results of the caecum fermentative activities by growing Black balady rabbits during the experimental period are presented in Table (8) results revealed that no significant differences were found between treatments in caecal $\mathrm{pH}$ value. However, caecal TVFAs concentration was significantly increased $(\mathrm{P}<0.05)$, while ammonia concentration was mostly insignificantly decreased with increasing of chicory supplementation compared with T0 that free the from herb. Chicory plant is a good and very important protective source for hepatocytes and other liver cells as well as it is used as prebiotic against some species of pathogenic bacteria for both in vitro and in vivo. Moreover it enhances immunity and feed efficiency by decreasing pathogenic microorganisms of gastrointestinal tract. Chicorium intybus roots also were used for the relief of mild digestive disorders such as feeding flatulence, abdominal fullness, temporary loss of appetite and slow digestion. Importantly, chicory working as feed additive used to improve growth and productive performance of poultry as well as salient beneficial applications in animals and humans (Saeed et al., 2017). Furthermore, Liu et al. (2013) concluded that inclusion of chicory (high in pectin) affects gut morphology and gut microbiota community composition differently from cereal fiber. These results are supported with those obtained by Cardinali et al. (2013) who found that, the dietary administration of red fresh chicory (leaves and roots) to young rabbits before weaning increased $(\mathrm{P}<0.05)$ the caecum weight and improved biochemical traits of caecum content: the increased VFA $(\mathrm{P}<0.05)$ content indicated a higher fermentation of gut microflora. They were concluded that, these results can imply that red chicory could be considered an additive rather than a feed. Similarly, chicory roots has a high content of fructooligosaccharides (FOS) and inulin, which can be used to manipulate the composition of microflora in the gut and enhances its integrity (Flickinger et al., 2003). Also, they found that inulin could have positive effects on the health status of post-weaned rabbits. In order to modulate caecal fermentation, some authors have used various FOS (Maertens et al., 2004), which are not digested in the upper intestine and remain available for fermentation by the caecal flora (Fishbein et al., 1988). Additionally, Gidenne and Perez (1994) reported that the low digested fibers (lignin and cellulose) play a key role in the digesta retention time, while Gidenne et al. (2004) indicated that the more digestible fibers (hemicellulose and pectins) enhance caecal microbial activity as observed in present study (in Tables 4 and 8). Regarding the influence of chicory ingestion on the caecal parameters, the major final metabolites of FOS and inulin are short-chain fatty acids, mainly propionate and butyrate (Gibson, 2004), which could contribute to the higher VFA and lower $\mathrm{pH}$ values. Also, showed lower ammonia content could be the result of the lower protein content of chicory. Ferguson et al. (1998) observed that a reduction of crude protein in the broiler diet equilibrates the ammonia concentration and reduces litter nitrogen. 
Table (8): Caecum activity as affected by chicory level in the diets of growing rabbits.

\begin{tabular}{cccc}
\hline \multirow{2}{*}{ Treatment } & \multicolumn{3}{c}{ Caecum activity } \\
\cline { 2 - 4 } & $\mathrm{pH}$ & TVFAs $(\mathrm{mq} / \mathrm{dl})$ & Ammonia $(\mathrm{mq} / \mathrm{dl})$ \\
\hline T0 & 7.07 & $1.10^{\mathrm{c}}$ & $17.92^{\mathrm{a}}$ \\
T1 & 6.93 & $1.35^{\mathrm{b}}$ & $17.50^{\mathrm{ab}}$ \\
T2 & 7.20 & $2.10^{\mathrm{a}}$ & $16.52^{\mathrm{b}}$ \\
T3 & 7.13 & $1.40^{\mathrm{b}}$ & $17.23^{\mathrm{ab}}$ \\
\pm SE & \pm 0.076 & \pm 0.113 & \pm 0.206 \\
\hline
\end{tabular}

Means bearing different letter superscripts $(a, b$ and $c)$ within the same column are significantly $(P \leq 0.05)$ different. $\quad S E$ $=$ standard error

$T O=$ group fed the basal diet (control), $T 1=$ group fed the basal diet with $0.25 \mathrm{~g}$ chicory, $T 2=$ group fed the basal diet with $0.75 \mathrm{~g}$ chicory and $\mathrm{T3}=$ group fed the basal diet with $1.25 \mathrm{~g}$ chicory.

\section{Economic efficiency}

The results of economical evaluation (Table 9) showed that marked improvement in feed cost per head was noted with incorporated chicory in the tested diets (T2 and T3) in comparison with the control one (T0). The calculated net revenue and economical efficiency indicated that 0.75 and $1.25 \mathrm{~g}$ chicory supplementation (T2 and T3) diets were much better (22.87\% and 22.54\%) and (1.30\% and $1.34 \%)$, respectively. While the lower values were occurred with either those received $0.25 \mathrm{~g}$ chicory or those of control diet. On the same line, Jenkins (2010) reported that chicory is highly digestible with low to moderate protein contents and could be included in beef cattle diet as an economical feed source. Also, Boraei et al. (2013) recommended to utilize medicinal herbs as feed supplements to rations of growing lambs, since it led to an improvement $(\mathrm{P}<0.05)$ for lambs ruminal measurements, increased feed intake, accelerated daily gain, feed utilization and maximize the net profit value/kg gain.

Table (9): Economical efficiency as affected by chicory levels in the diet of growing rabbits.

\begin{tabular}{|c|c|c|c|c|c|}
\hline \multirow{2}{*}{ Item } & \multicolumn{4}{|c|}{ Treatment } & \multirow{2}{*}{$\pm \mathrm{SE}$} \\
\hline & T0 & $\mathrm{T} 1$ & $\mathrm{~T} 2$ & T3 & \\
\hline Price/ kg diet (L.E) & 4.19 & 4.19 & 4.20 & 4.20 & \\
\hline Total feed intake/ rabbit (g) & $3958.31^{c}$ & $4157.11^{\mathrm{b}}$ & $4377.54^{\mathrm{a}}$ & $4182.51^{\mathrm{b}}$ & \pm 22.73 \\
\hline Total feed cost /rabbit (L.E) & 17.53 & 18.40 & 17.58 & 16.84 & \\
\hline Total weight gain/ rabbit (g) & $986.67^{\mathrm{b}}$ & $1037.50^{\mathrm{ab}}$ & $1155.81^{a}$ & $1125.00^{\mathrm{ab}}$ & \pm 27.941 \\
\hline Total feed cost / kg gain (L.E) & 17.77 & 17.74 & 15.21 & 14.97 & \\
\hline Total revenue / rabbit (L.E) & 34.53 & 36.31 & 40.45 & 39.38 & \\
\hline Net revenue/ rabbit (L.E) & 17.00 & 17.91 & 22.87 & 22.54 & \\
\hline Economical efficiency (E.EF) & 0.970 & 0.973 & 1.30 & 1.34 & \\
\hline Relative E. EF \% & 100 & 100.3 & 134.1 & 137.9 & \\
\hline
\end{tabular}

Means bearing different letter superscripts $(a, b$ and $c)$ within the same row are significantly $(P \leq 0.05)$ different.

The price of one ton of clover hay $(12 \% \mathrm{CP})$, barley grains, yellow corn, soybean meal (44\%CP), wheat bran, molasses, methionine, Vitamins \& minerals mixture, Salt, limestone and Di-Calcium phosphate were 2400, 5000, 4000, 7500, 3200, 2000, 70000, 25000, 500, 400, 10000 L.E, respectively. Prices of one kg chicory and body weight on selling were 5 and 35 L.E, respectively.

Net revenue/ rabbit $(L . E)=($ Total revenue $/$ rabbit $(L . E))-$ Total feed cost /rabbit $($ L.E $))$.

Economical efficiency $=$ Net revenue/ rabbit (L.E)/Total feed cost/rabbit (L.E).

Total feed cost $/ \mathrm{kg}$ gain $=$ Total feed cost $/$ rabbit $($ L.E $) \times 1000 /$ Total weight gain $/$ rabbit $(\mathrm{g})$. 


\section{CONCLUSION}

It could be concluded that including dried chicory leaves at $0.75 \mathrm{~g}$ into the basal diet may be useful as it improved productive performance, nutrients digestibility and carcass traits. Moreover, chicory addition appear to reflect a good hepatic function and caecum fermentative activities. So, $0.75 \mathrm{~g}$ chicory addition could be safely, successfully and economically used for growing rabbits.

\section{REFERENCES}

Abou-Zied, E. N. (1988). Aromatic seeds and its products (Text.Book, in Arabic). El-Dar El-arabia for publication. Cairo, Egypt.

Adamoli, R. and D. Rigon (2001). Inulin and oligofructose in huma nutrition. Functional foods for promoting health. Latte, 26:72-81.

AMD (1996). The Standard Properties for Ingredients, Feed Addetives and Feed Manufactured for Animal and Poultry, El-Wakaee.

Ali Mirza Aghazadeh and Elena Nabiyar (2015). The effect of chicory root powder on growth performance and some blood parameters of broilers fed wheat based diets. Journal of Applied Animal Research, Vol. 43, No. 4, 384-389.

Allian, C. C.; L. S. Poon; C. S. G. Chan and W. Richmond (1974). Enzymatic determination of total serum cholesterol. Clin. Chem., 20:470-475.

Ando, S.; T. Nishida; M. Ishida; K. Hosoda and E. Bayaru (2003).Effect of peppermint feeding on the digestibility, ruminal fermentation and protozoa, Livestock Production Science, Vol. 82, p. 245248.ISSN 0301-6226.

AOAC (1996). Association of Official Analytical Chemists. Official Methods of Analysis, $16^{\text {th }}$ edition, Washington, USA.

Athanasiadou, S.; D. Gray; D. Younie; O. Tzamoloukas; F. Jackson and I. Kyriazakis (2007). The use of chicory for parasite control in organic ewes and their lambs. Parasitology, 134: 299-307.

Behboud Jafari, Ali rezaie and Elmira Habibi (2011). Comparative Effect of chicory (cichorium intybus 1.) and Nigella sativa extract with an antibiotic on different parameters of broiler chickens. J. Appl. Environ. Biol. Sci., 1,11:525-528.

Blasco, A.; J. Ouhayoun and G. Masoero (1993). Harmonization of criteria and terminology in rabbit meat research. World Rabbit Sci., 1: 3-10.

Boraei, M. A.; sh. M. Fouda and M. A. I. El-Syss (2013). Effect of medicinal herbs supplementation on the feeding value and the performance of local crossbred male lambs. Egyptian J. Nutr. and feeds, 16(3):427436.

Cardinali, R.; A. Dal Bosco and C. Castellini (2013). Effect of dietarysupplementation of fresh red chicory (Chicorium intybus foliosum) on gastro-intestinal tract and caecal fermentation of rabbit before weaning. Giornate di Coniglicoltura ASIC. Email: rcardinali@inwind.it

Castellini, C.; R. Cardinali; P.G. Rebollar; A. Dal Bosco; V. Jimeno and M.E. Cossu (2007). Feeding fresh chicory (Chicoria intybus) to young rabbits: Performance, development of gastro-intestinal tract and immune functions of appendix and Peyer's patch. Animal Feed Science and Technology, 134, 56-65.

Cheeke, P.R. (1987). Rabbit Feeding and Nutrition. Academic Press. Orlando, Florida, USA.

Coles, E.H. (1986). Veterinary Clinical Pathology, 4th. ED. W.B. Saunders Company, London.

Conway, E.F. (1963). Modification Analysis Method for Determining Ammonia in Compound. Analytical compound and volumetric error. Rev. ED. Look Wood, London. 


\section{Mahmoud}

Craig, W.J. (1999). Health-promoting properties of common herbs. American Journal of Clinical nutrition, 70, No. 3: 491S-499S.

Das, S.; N. Vasudeva and S. Sharma (2016). Chicoria intybus a concise report on its ethanomedicinal, botanical and phytopharmacological aspects, During Development and Therapeutics, vol 7, No.1, pp. 112.

Di Venere, D.; L. Sergio; V. Linsalata; M. Pieralice; A. Cardinali; N. Cascarano and V.V. Bianco (2009). Proprieta antiossidanti di specie erbacee spontanee eduli. It J. Agron./Riv. Agron., 4 (Suppl. 4): 635-640 (in Italian).

Doumas, B.T.; W.A. Watson and H.G. Biggs (1971). Albumin standareds and measurement of serum with bromocresol green. Clin. Chem. Acta, 31(1): 87-96.

Duncan, D.B. (1955). Multiple ranges and multiple F-test. Biometric, 11:1-42.

El-Basiony A.Z.; H.M. Khattab; A.M. Kholif; Fatma I. I. Hadhoud and H.A. El-Alamy (2015). Effect of using Echinacea purpurea, Nigella sativa and Chicorium intybus in dairy goats' diet on milk production and quality: 2- effect on digestibility, some blood parameters and milk production and quality Egyptian J. nutrition and feeds, 18(2) special issue: 137-145.

Ferguson, N.S.; R.S. Gates; J.L. Taraba; A.H. Cantor; A.J. Pescatore; M.J. Ford and D.J. Burnham (1998). The effect of dietary crude protein on growth, ammonia concentration, and litter composition in broilers. Poultry Sci., 77: 1481-1487.

Fishbein, L.; M. Kaplan and M. Gough (1988). Fructo-oligosaccharides: a review. Vet. Hum.Toxicol, 30: 104-105.

Flickinger, E.A.; J. VanLoo and G.C. Fahey (2003). Nutritional responses to the presence of inulin and oligofructose in the diets of domesticated animals. A review. Crit. Rev. Food Sci. Nutr., 43: $19-60$.

Gibson, G.R. (2004). Dietary modulation of the human gut microflora using the prebiotics oligofructose and inulin. J. Nutr., 2: 259-275.

Gidenne T. and J.M. Perez (1994). Apports de lignines ET alimentation du lapin en croissance. I. Conséquences sur la digestion etle transit. Ann. Zootech,, 43: 313-322.

Gidenne T.; L. Mirabito; N. Jehl; J.M. Perez; P. Arveux; A. Bourdillon; C. Briens; J. Duperray and E. Corrent (2004). Impact of replacing starch by digestible fibre, at two levels of lignocellulose on digestion, growth and digestive health of the rabbit. Anim. Sci., 78: 389-398.

Hanna, A. H. and I.Y. Mokhtar (2010). Ameliorating effect of Cichorium intybus L. supplemented diet against nitrosamine precursors-induced liver injury and oxidative stress in male rats. Food and Chemical Toxicology, 48: 2163-2169.

Henry, R.J.; D.C. Cannon and W. Winkelman (1974). Clinical chemistry principals and techniques, $11^{\text {th }}$ ed. pp. 1629. Happer and Row Publishers, New York, USA.

Ibolya Kocsis; Krisztina Hagymási; Ágnes Kéry, Éva SzŐke and Anna Blázovics (2003). Effects of chicory on pancreas status of rats in experimental dislipidemia. Acta Biologica Szegediensis, 47 (1-4): 143-146.

Jenkins, K.H. (2010). Feed value of alternative crops for beef cattle. University of Nebraska-Lincoln Animal Science Departement.

Liu, H.Y.; E. Ivarsson; T. Lundh and J. E. Lindberg (2013). Chicory (Cichorium intybus L.) and cereals differently affect gut development in broiler chickens and young pigs. J. Anim. Sci and Biotechnology, 4, 1: 50 .

MOA (2001). Feed Composition Tables for Animal and Poultry Feedstuff Used in Egypt. Technical Bulletin No. 1, Central Lab for Feed and Food, Ministry of Agriculture, Egypt.

Maertens, L.; J.M. Aerts and J. De Boever (2004). Degradation of dietary oligofructose and inulin in the gastrointestinal tract of the rabbit and the effects on caecal $\mathrm{pH}$ and volatile fatty acids. World Rabbit Sci., $12,235-246$. 
Massoud, Mona I..; Wafaa A. Amin and A.A. Elgindy (2009). Chemical and Technological Studies on Chicory (Cichorium intybus L.) and its Applications in some functional food. J. Adv. Agric. Res., (Fac. Ag. Saba Basha) 14 (3), 735-756.

Monti, A.; M.T. Amaducci; G. Pritoni and G. Venturi (2005). Growth fructan yield, and quality of chicory (Cichorium intybus L.) as related to photosynthesis capacity, harvest time and water regime. Journal of Experimental Botany, 56:1389-1395.

Moussa, M.M.; Mona, I. Massoud and M.A Zeitoun (2005). Identification of volatile compounds extracted from certain medical plants, Alex. J.Fd. Sci. \& Technol., 2:9-18.

Nobakht Ali (2011). Effects of different levels of chicory (Cichorium intybus L.), zizaphora (Zizaphora tenuior L.), nettle (Urtica dioica L.) and savoury (Satureja hortensis L.) medicinal plants on carcass characteristics of male broilers. Journal of Medicinal Plants Research, 5(17): 4354-4359.

North, M.O. (1981). Chommercial chicken production manual. $3^{\text {rd }}$ Ed, Avi., Publishing Company. I.N.C. Westport Connectcut, USA.

Reitman, S. and S. Frankel (1957). A colorimetric method for determination of serum glumaticoxaloacetic and glutamic pyruvic transaminases. Ann. Journal of clinical pathology, 26:1-13.

Saeed, M.; M.E. Abd El-Hack; M. Alagawany; M.A Arian, M. Arif; M.A. Mirza; M. Naveed; S. Chao; M. Sarwar; M. Sayab and K. Dhama (2017). Chicory (Chicorium intybus) herb: Chemical composition, Pharmacology, Nutritional and healthical application. Intr, J. of pharmacology, Vol. 13 (4):351-360.

Sanderson M.A.; M. Labreveux; M.H. Hall and G.F. Elwinger (2003). Nutritive value of chicory and English plantain forage. Crop Sci., 43: 1797-1804.

SAS (2000). SAS-User's Guide: Statistics. SAS Instute Inc., Cary, NC., USA.

Scharenberg, A.; Y. Arrigo; A. Gutzwiller; C.R. Soliva; U. Wyss; M. Kreuzer and F. Dohme (2007). Palatability in sheep and in vitro nutritional value of dried and ensiled sainfoin (Onobrychis viciifolia) birdsfoot trefoil (Lotus corniculatus) and chicory (Cichorium intybus). Arch. Anim. Nutr., 61: 481-496.

Socode (2011). Ground and dehydrated chicory pulp. http://www.socode-warcoing.be/en/fibres pulpe.htm.

SooBo, S. (2005). Effects of Prebiotics, Probiotics and synbiotics in the diet of young pigs (dissertation), Wageningen University Netherlands.

Stroev, E. A. (1989). Biochemistry Text Book, MIR Publishers, MOSCOW.

Tietz, N. W. (1986). Text book of Clinical Chemistry, Saunders, Philadelphia.

Volk, Z. and M. Marounek (2011). Dried chicory root (Cichorium intybus L.) as a natural fructan source in rabbit diet: Effects on growth performance, digestion and caecal and carcass traits. World Rabbit Sci., 19: 143-150.

Waldroup AL.; J.T. Skinner; R.E. Hierholzer and P.W. Waldroup (1993). An evaluation of froctoolligosaccharide in diets for broiler chickens and effects on salmonella contamination of carcasses. Poult Sci., 72:643-650.

Walter, R. (1995). Dietetic feeds and nutritional supplements. In: Biotechnology in the feed industry. Proceedings of Alltech's Eleventh Annual Symposium. Pp.143 (Ed.). TP Lyons and KA lacques UK.

Wang, Q. and J. Cui (2009). A review on pharmic effect of chicory research and development. Zhongguo Zhong Yao Za Zhi., Sep; 34(17):2269-72.

Warner, A.C.I. (1964). Production of volatile fatty acids in the rumen, method of measurements. Nut. Abst. and Rev., 34: 339.

Yusrizal, C. and C. Chen (2003). Effects of adding chicory fructans in feed on broiler growth performance, serum cholesterol and intestinal length. Intr. J. Poult. Sci., 2: 214-219. 


\section{Mahmoud}

\section{إستخدام أوراق عثب الثيكوريا الجافة فى علائق الأرانب}

\section{ياسمين محمود محمد محمود \\ معطج بحوث الإنتاج الحيوانس، مركز البحوث النزراعية، وزارة الزراعة، الدقى، جيزة، مصر}

أجريت هذه التجربة بمحطة بحوث الإنتاج الحيو انى بسخا ـ كفر الثيخ بهذف دراسة ثأثير بعض الإضافات الغذائية (عشب الثيكوربا

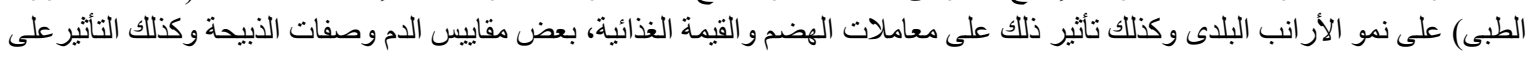
النشاط الميكروبى فى أعور الأرانب.

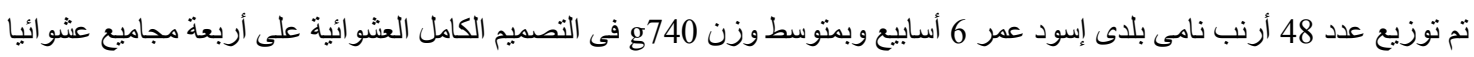

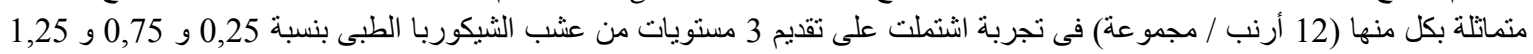
جرام / أرنب إضافة إلى عليقة الضابطة (الكنترول) وغذيت المجمو عات كلها على على عليقة أساسية موحدة تفى بالاحتباجات الغذائية وتحتوى على 17\% برونين.

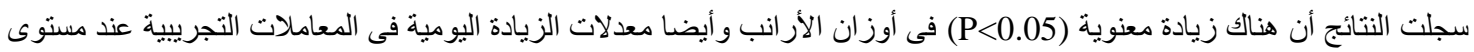

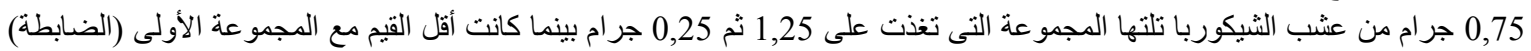

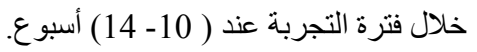

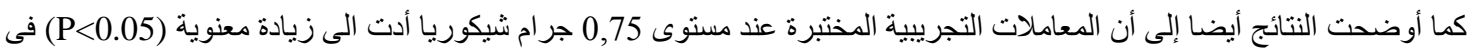

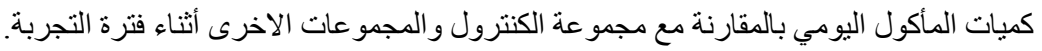

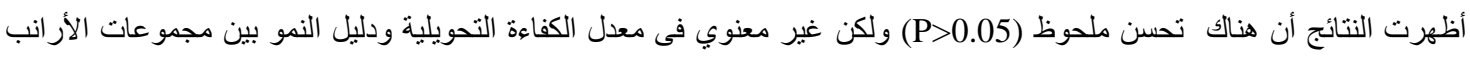
المغذاة على المستويات المختلفة من الثيكوريا ومجموعة الكنترول.

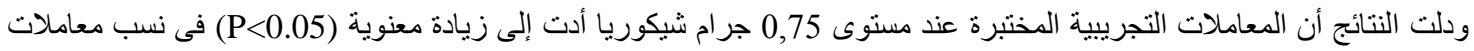

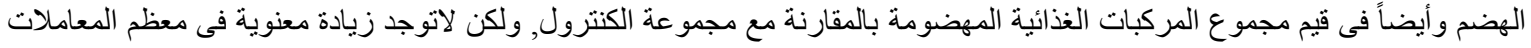
التجريية المختبرة الأخرى بالمقارنة مع مجمو عة الكنترول.

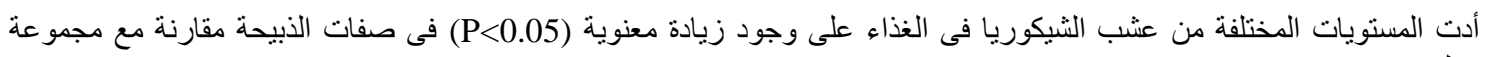
الكنترول.

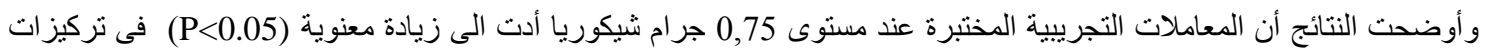

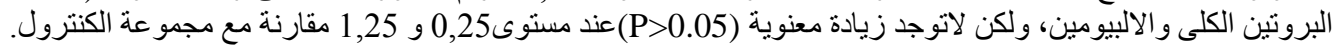

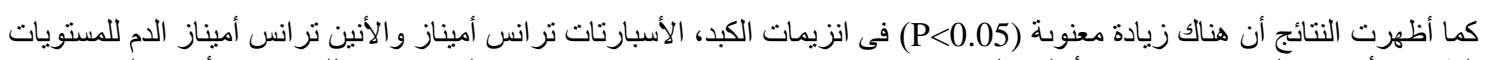
المختلفة من أوراق الثنيكوريا وكانت أعلي القيم عند مستوى

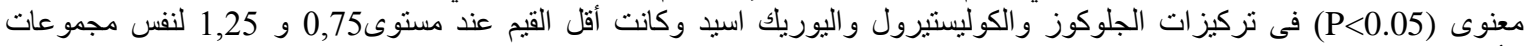
الأرانب بالمقارنة مع مجموعة الكنترول.

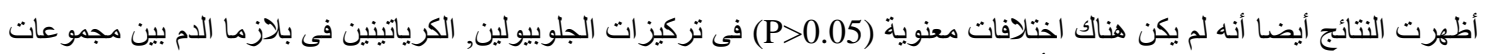

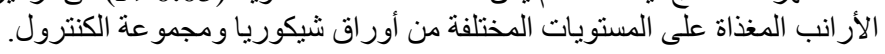

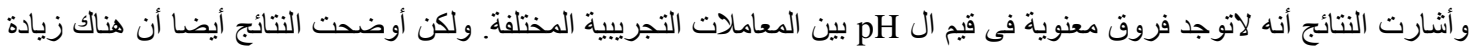

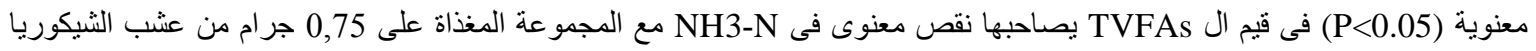

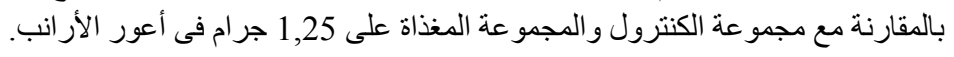
نخلص من هذه النتائج أنه يمكن إستنتاج إضافة عشب الثنيكوريا عند مستوى 0,75 جرام في علائق الأرانب. 